\title{
PENGEMBANGAN ALAT UKUR BEBAN KERJA MENTAL PERAWAT DALAM INTERAKSI ASUHAN KEPERAWATAN
}

\author{
Ati Surya Mediawati ${ }^{1}$, Elly Nurachmah ${ }^{2}$, \\ Muchtaruddin Mansyur ${ }^{3}$, Tries Eryando ${ }^{4}$ \\ ${ }^{1}$ Departemen Keperawatan Dasar, Fakultas Keperawatan Universitas Padjadjaran \\ ${ }^{2}$ Fakultas Keperawatan, Universitas Indonesia \\ ${ }^{3}$ Fakultas Kedokteran, Universitas Indonesia \\ ${ }^{4}$ Fakultas Kesehatan Masyarakat, Universitas Indonesia \\ E-mail: ati_suryamediawati@yahoo.com, ellynur08@yahoo.co.id,m_mansyur@yahoo.co.id
}

\begin{abstract}
ABSTRAK
Ketika melakukan asuhan keperawatan, perawat perlu berinteraksi dengan klien. Interaksi dapat dilaksanakan dengan baik apabila perawatannya mampu beradaptasi dengan beban kerja mental yang dimanifestasikan ke dalam gejala fisik, psikologis, dan perilaku yang ditampilkan. Tujuan penelitian: mengembangkan alat ukur beban kerja mental saat berinteraksi dengan klien dalam pemberian asuhan keperawatan. Metode: Penelitian menggunakan metode deskriptif analitis. Alat ukur dikembangkan dengan menggunakan pendekatan interpretasi terhadap skala interval dan skala ordinal yang diisi oleh 596 partisipan yang diproses melalui sebelas case processing data. Penelitian dilaksanakan di provinsi Jawa Barat, Jawa Tengah, Sumatra Barat, dan Sulawesi Selatan. Validitas dan reliabilitas variabel persepsi Teruji $(p=0,996$ sebelum interaksi dan $p=0,993$ setelah interaksi), observasi $(p=0,844$ sebelum interaksi, $p=0,711)$ orientasi $(p=0,711)$, identifikasi $(p=0,769)$, eksplorasi $(p=0,773)$, resolusi $(p=0,820)$, setelah interaksi $(p=0,772)$, angket klien $(p=0,64)$. Hasil: Hasil pengujian model Confirmatory Factor Analysis (CFA) melalui program Lisrel menghasilkan $p$-value $=0,150(p>0,05)$ dan RMSEA $=0,075$ (RMSEA $<0,1)$. Diskusi: Diperlukan dukungan regulasi sebagai implikasi dalam penggunaan alat ukur. Simpulan: alat ukur ini vaild dan reliabel sebagai informasi diagnostik pengukuran beban kerja mental.
\end{abstract}

Kata Kunci: alat ukur, beban kerja mental, interaksi.

\section{ABSTRACT}

Nurses in providing nursing care need to interact with clients. Such interaction can be successfully performed if the treatment can adapt to mental workload which is manifested into physical, psychological and behavioral symptoms. Objectives: developing a mental workload instrument when interacting with clients in providing nursing care. Methods: It employed a descriptive analytic method. The instrument was developed by employing the approach to the interpretation of scale interval and ordinal scale which were filled by 596 participants and processed through 11 case processing data. The research was conducted in the provinces of West Java, Central Java, West Sumatra and South Sulawesi. Validity and reliability of the perception variables were tested $(p=0.996$ before the interaction and $p=0.993$ after the interaction), observation ( $p=0.844$ before the interaction, $p=0.711)$, orientation $(p=0.711)$, identification $(p=0.769)$, exploration $(p=0.773)$, resolution $(p=0.820)$, after the interaction $(p=0.772)$, client questionnaire $(p=0.64)$. Results: The results of Confirmatory Factor Analysis (CFA) usingLisrel software indicated $p$-value $=0.150(p>0.05)$ and $R M S E A=0.075$ (RMSEA <0.1). Discussion: Regulatory support is needed as an implication for the use of the instrument. Conclusion: This instrument is valid and reliable to measure mental workload for diagnostic information.

Keywords: instrument, mental workload, interaction. 


\section{LATAR BELAKANG}

Keluarnya keputusan menteri kesehatan No. 659/Menkes/Per/VIII/2009 tentang standar dan kriteria rumah sakit kelas dunia, perlu disertai dengan pedoman pelayanan keperawatan mengingat perawat berada terbanyak dan terlama di samping klien. Keputusan tersebut menunjukkan bahwa keperawatan saat ini dihadapkan pada tuntutan masyarakat terhadap pelayanan keperawatan untuk memberikan pelayanan berfokus pada klien, pengelolaan pelayanan keperawatan yang berstandar internasional dan menjaga keselamatan klien.

Interaksi diperlukan untuk pengembangan karakteristik peran perawat, sehingga asuhan keperawatan yang diberikan dapat diimplementasikan (Joint Commision Resources, 2005). UndangUndang keperawatan nomor 38 tahun 2014 pasal 38 ayat a menyebutkan dalam praktik keperawatan, klien berhak mendapatkan informasi secara benar, jelas, dan jujur tentang tindakan keperawatan yang akan dilakukan. Menurut King dalam Tomey dan Alligood (2014), perawat menempatkan diri sebagai "I and the self." Selama berinteraksi dengan klien, perawat harus memahami dan mampu mengendalikan diri dalam berbagai situasi emosi klien yang tidak dapat diprediksi. Sebagai individu perawat harus memiliki kemampuan adaptasi, penyelesaian tugas, penggunaan fasilitas yang dibutuhkan walaupun telah melalui uji kualifikasi profesional yang sama. Individu akan mampu menunjukkan optimalisasi dan menyeimbangkan perilaku dirinya dengan lingkungannya (Peterson dan Bredow, (2013).

Menurut Pheasant, Stephen (1991), penurunan kinerja dapat terjadi saat seseorang tidak termotivasi lagi untuk menghasilkan performa yang adekuat. Pada kondisi tersebut terjadi beban kerja mental. Seorang perawat selalu dihadapkan pada enam aspek yang memengaruhi, yaitu beban kerja, pengendalian, penghargaan, masyarakat, keadilan, dan nilai-nilai sehingga dapat menyebabkan kejenuhan. Selama berinteraksi dengan klien, sering kali perawat mengeluh mengalami ketidakseimbangan emosi dan menghadapi kesulitan untuk dapat mempertahankan hasil kerja yang optimal. Kegagalan mengoptimalkan tenaga perawat akan berdampak terhadap kelelahan mental perawat.

Hasil penelitian Erickson dan Grove (2007) terhadap 843 perawat menunjukkan peningkatan emosi perawat sangat dipengaruhi oleh stressor yang muncul. Dalam memberikan asuhan keperawatan langsung, perawat berusia di bawah 30 tahun kurang mampu mengelola emosinya dengan angka kelelahan lebih tinggi, sehingga membutuhkan mentor dalam emosional. Menurut Maslach dan Leiter (2008), seorang perawat setiap harinya selalu dihadapkan pada situasi ketakutan, kelelahan, sedih, tidak berdaya. Kondisi ini mengakibatkan kejenuhan. Hasil penelitian perawat yang berusia di bawah 30 tahun dalam pemberian asuhan keperawatan sangat dipengaruhi oleh kemampuan mengekspresikan emosinya. Sebesar 38 persen angka kelelahan mental perawat yang selalu menekan perasaan emosinya, sedangkan angka kelelahan mental perawat yang dapat mengekspresikan emosinya sebesar 23 persen (Gabbay dan Bukchin, 2009).

Survei pendahuluan dilakukan oleh peneliti di lima rumah sakit di Jawa Barat tahun 2010 yaitu RS. Hasan Sadikin, RS. Cibabat, RS. Soreang, RS. Ujung Berung, dan RS. Tasikmalaya pada 150 orang perawat bedah. Hasil penelitian diperoleh data hampir 83 persen bekerja dalam kondisi beban kerja mental. Selama berinteraksi dengan klien pra dan pasca operasi perawat membutuhkan upaya mental (skala 7), 
upaya fisik (skala 4), upaya pengelolaan waktu (skala 8), upaya memenuhi tuntutan performa (skala 8), mengalami frustrasi (skala 8) dan upaya memenuhi fisik dan membutuhkan pengorbanan mental (skala 7).

Menurut Maslach dan Leiter (2008), perawat membutuhkan kematangan emosi untuk melaksanakan tugasnya. Perawat sebagai manusia memiliki keterbatasan untuk tetap termotivasi bekerja dalam kontrol yang aman. Bila ketidakseimbangan tuntutan dan keterbatasan kemampuan selama berinteraksi dalam pemberian asuhan keperawatan berlangsung secara terus menerus akan memengaruhi beban kerja mental. Menurut Yustinus (2006) kelelahan mental (mental fatigue) terjadi akibat aktivitas mental, emosi, dan jiwa secara berulang. Kelelahan mental terlihat pada tingkah laku yang tidak konsisten, kondisi fisik dan jiwa yang labil terhadap perubahan lingkungan.

Menurut King dalam Tomey dan Alligood (2014) interaksi antara perawat dengan klien terjadi saling merespons, bertukar energi, dan mengontrol stressor sehingga dapat memenuhi kebutuhan klien. Dalam berinteraksi dibutuhkan kemampuan perawat mendayagunakan sumber secara optimal. Perawat sebagai manusia memiliki keterbatasan untuk termotivasi bekerja dalam kontrol yang aman. Hasil dari studi pendahuluan menunjukkan keterbatasan perawat pada umumnya meliputi keterbatasan waktu dalam pemberian asuhan keperawatan, tugas yang kurang spesifik, keterbatasan kemampuan, kurangnya motivasi untuk melaksanakan tugas keperawatan, dan suasana hati yang tidak seimbang. Bila keterbatasan perawat beradaptasi dengan beban kerja mental berlangsung secara berulang akan memengaruhi beban kerja mental dan dapat memengaruhi kegiatan berinteraksi sehingga berdampak terhadap pelaksanaan asuhan keperawatan klien secara terorganisir. Berbagai profesi telah memiliki instrumen pengukuran beban kerja mental ini dalam berbagai perspektif sehingga mereka selalu berada dalam kondisi "safe control" untuk melakukan pekerjaan. Sementara itu sampai saat ini belum ada alat ukur beban kerja mental selama berinteraksi dengan klien yang benar-benar dikembangkan untuk perawat. Pimpinan keperawatan perlu menyadari sedini mungkin terjadinya beban kerja mental selama berinteraksi dengan klien dalam pemberian asuhan keperawatan.

\section{METODE}

Desain penelitian ini bersifat deskriptif analitis yaitu untuk mengembangkan alat ukur beban kerja mental saat berinteraksi dengan klien dalam pemberian asuhan keperawatan. Tahapan dalam penelitian ini meliputi tahap studi pendahuluan, spesifikasi alat ukur, uji coba, uji validitas dan reliabilitas, perluasan uji coba pengembangan alat ukur, serta tahap pengujian model.

Kriteria penelitian yang digunakan adalah ruang perawatan klien dewasa, klien mampu berinteraksi, klien bersedia untuk melaksanakan interaksi, dan tidak membedakan kelas perawatannya. Pengembangan alat ukur beban kerja mental saat interaksi dalam asuhan keperawatan disusun berdasarkan hasil studi pendahuluan dan uji coba penelitian melalui metode penelitian triangulasi sesuai dengan petunjuk yang dikemukakan oleh Creswell (2010). Alat ukur selanjutnya dikembangkan menjadi dua jenis respons jawaban yang diminta yaitu tipe pengukuran subjektif dan objektif.

Alat ukur dirancang berdasarkan teori dinamic interaction system dari Imogene King (1981) dalam Tomey dan Alligood (2014), teori interpesonal dari Hildegard Peplau (1952), serta hasil pengembangan alat ukur beban kerja mental yang telah 
dikembangkan oleh NASA-TLX (Nasa Task Load Indeks) dan RSME (Rating Scale Mental Effort). Awalnya alat ukur yang akan dikembangkan hanya dua jenis, yaitu alat ukur persepsi Teruji dan hasil observasi dari penguji. Berdasarkan hasil penilaian para ahli perlu dikembangkan menjadi 4 bagian yaitu penambahan penilaian klien dan pendamping.

Hasil studi pendahuluan dan uji coba penelitian untuk persepsi Teruji digunakan skala Likert 0-10. Skala ini dipilih untuk menghindarikecenderungan Teruji menjawab netral dan memilih respons yang cenderung ke arah tertentu. Alat ukur observasi yang dilakukan oleh penguji, pendamping dan klien menggunakan metode Gutman (Nazir, 2003), yaitu menyediakan dua pilihan mulai dari "tidak berubah" sampai "berubah" terhadap kondisi hasil pengamatan perilaku, psikologis, dan fisik. Alternatif jawaban tersebut dipilih Teruji agar lebih objektif dalam memberikan jawaban sesuai hasil observasinya.
Pengembangan alat ukur klien ini dilakukan dengan cara menginventarisasi perubahan perilaku yang dapat terjadi selama interaksi, menelaah isi butir pertanyaan dan menulis butir-butir pertanyaan. Penilaian antar-teman dilakukan secara retrosfektif terhadap penampilan Teruji dan selama Teruji diobservasi oleh pendamping selama berinteraksi dengan klien. Butirbutir pertanyaan disusun sesuai dengan perubahan perilaku sebelum dan selama interaksi. Tujuan penilaian ini adalah untuk mengklarifikasi perubahan fisik, perilaku Teruji saat berinteraksi dengan klien dalam asuhan keperawatan. Uji coba alat ukur dilakukan di rumah sakit vertikal di empat provinsi Jawa Barat, Jawa Tengah, Sumatra Barat, dan Sulawesi Selatan, dilaksanakan pada bulan Juni sampai September 2014. Seluruh partisipan dalam penelitian ini berjumlah 596 orang yang meliputi Teruji (195 orang), penguji (11 orang), pendamping (195 orang) dan klien (195 orang).

HASIL

Tabel 1. Data demografi penyebaran partisipan berdasarkan jenis kelamin, tempat bekerja, dan pengalaman kerja ( $n=$ partisipan $=195$ orang)

\begin{tabular}{llcc}
\hline \multicolumn{1}{c}{ Jenis Kelamin } & Tempat Bekerja & Pengalaman Kerja & (\%) \\
\hline \multirow{3}{*}{ Laki-Laki } & \multirow{2}{*}{ Bedah } & 0-8 tahun & 11,9 \\
& & $>8-16$ tahun & 11,3 \\
& \multirow{2}{*}{ NonBedah } & 0-8 tahun & 16,8 \\
& & $>8-16$ tahun & 10 \\
Perempuan & \multirow{2}{*}{ Bedah } & $0-8$ tahun & 14,8 \\
& & $>8-16$ tahun & 12 \\
& \multirow{2}{*}{ NonBedah } & $0-8$ tahun & 11,5 \\
& & $>8-16$ tahun & 11,7 \\
\hline
\end{tabular}

Keterangan: ${ }^{*}=$ persentase tertinggi 
Berdasarkan Tabel 1, partisipan reliabilitas tentang beban kerja mental saat terbanyak berjenis kelamin laki-laki di unit interaksi dalam asuhan keperawatan dapat non rawat bedah (16,8 persen). Hașil uji dilihat pada Tabel 2 sebagai berikut.

Tabel 2. Hasil uji reliabilitas beban kerja mental saat interaksi dalam asuhan keperawatan periode Januari-Agustus 2014

\begin{tabular}{clc}
\hline No & \multicolumn{1}{c}{ Ranah Penelitian } & Cronbach \\
\hline 1 Persepsi Teruji & \\
& $\begin{array}{l}\text { 1. Sebelum interaksi } \\
\text { 2. Sesudah interaksi }\end{array}$ & 0,993 \\
2 & Hasil Observasi Menurut Persepsi Pendamping & 0,996 \\
& 1.Sebelum interaksi & \\
& 2.Selama interaksi & 0,928 \\
3 & Hasil Observasi Terhadap Perubahan Fisik, Psikologis, dan Perilaku & 0,907 \\
& 1.Sebelum interaksi & \\
& 2.Selama interaksi & 0,844 \\
& a. Orientasi & 0,711 \\
& b. Identifikasi & 0,769 \\
& c. Eksplorasi & 0,773 \\
& d. Resolusi & 0,82 \\
& 3.Setelah interaksi & 0,772 \\
Persepsi Klien setelah Interaksi & 0,56 \\
\hline
\end{tabular}

Tabel 2 menjelaskan bahwa angka dilakukan dengan menggunakan model reliabilitas tertinggi terdapat pada alat ukur Second Order Confirmatory Factor Analysis persepsi Teruji setelah berinteraksi. Analisis (SOCFA). Hasil uji coba alat ukur beban kontribusi dari observasi, persepsi Teruji, mental Teruji saat interaksi terdapat pada observasi pendamping, dan pendapat klien Tabel 3 sebagai berikut.

Tabel 3. Hasil uji coba alat ukur beban mental Teruji saat interaksi pada 195 partisipan

\begin{tabular}{|c|c|c|c|c|}
\hline \multicolumn{2}{|c|}{ Indeks Kecocokan } & \multirow[t]{2}{*}{$D f$} & \multirow[t]{2}{*}{$p$-value } & \multirow{2}{*}{$\frac{\text { Ket. }}{\text { Model Fit }}$} \\
\hline Chi-square & 119,35 & & & \\
\hline RMSEA & 0,099 & $d f=41$ & $p=0,000$ & Model Fit \\
\hline SRMR & 0,042 & & & Model Fit \\
\hline
\end{tabular}


Tabel 4. Besaran parameter model beban kerja mental saat interaksi

\begin{tabular}{|c|c|}
\hline Jenis Model & Angka Keterikatan \\
\hline \multicolumn{2}{|l|}{ Observasi } \\
\hline Sebelum & $\lambda=0.43, \mathrm{t}_{\text {hitung }}=0,00$ \\
\hline Orientasi & $\lambda=0.91, t_{\text {hitung }}=17,19$ \\
\hline Identifikasi & $\lambda=0.85, \mathrm{t}_{\text {hitung }}=15,27$ \\
\hline Eksplorasi & $\lambda=0.86, \mathrm{t}_{\text {hitung }}=0,00$ \\
\hline Resolusi & $\lambda=0.72, \mathrm{t}_{\text {hitung }}=11,83$ \\
\hline Sesudah & $\lambda=0.80, \mathrm{t}_{\text {hitung }}=13,85$ \\
\hline \multicolumn{2}{|l|}{ Persepsi Teruji } \\
\hline Sebelum & $\lambda=0.60, \mathrm{t}_{\text {hitung }}=0,00$ \\
\hline Sesudah & $\lambda=1.11, \mathrm{t}_{\text {hitung }}=1,60$ \\
\hline \multicolumn{2}{|l|}{ Pendamping } \\
\hline Sebelum & $\lambda=0.43, \mathrm{t}_{\text {hitung }}=0,00$ \\
\hline Selama & $\lambda=1.43, \mathrm{t}_{\text {hitung }}=1,50$ \\
\hline Klien & $\lambda=0.69, \mathrm{t}_{\text {hitung }}=0,00$ \\
\hline
\end{tabular}

Tabel 4 menunjukkan bahwa hampir semua muatan faktor 0,5 , artinya hampir semua indikator memberikan kontribusi terhadap model pengukuran beban kerja mental, saat interaksi asuhan keperawatan. Sedangkan yang tidak memberikan kontribusi terhadap model asuhan yaitu model alat pendamping sebelum dilaksanakan interaksi yaitu sebesar 0,43 . Hasil tersebut menunjukkan bahwa model alat ukur beban kerja mental perawat yang penilaiannya dilakukan oleh pendamping sebelum pelaksanaan penelitian tidak menunjukkan keterikatan yang kuat dibandingkan dengan model pengukuran beban kerja mental perawat dalam interaksi asuhan keterujian, sehingga faktor penilaian pendamping sebelum interaksi dipertimbangkan untuk dieliminasi.

Untuk mendapatkan hasil pemodelan yang valid dan reliabel maka dilakukan uji modifikasi terhadap model tersebut, sehingga diperoleh hasil yang terlihat dalam Tabel 5 tentang indeks kesesuaian beban kerja mental Teruji. 
Tabel 5. Indeks kesesuaian beban kerja mental teruji saat interaksi pada 195 partisipan

\begin{tabular}{lcccc}
\hline \multicolumn{1}{c}{ Indeks Kecocokan } & & df & p-value & Ket. \\
\hline Chi-square & 7,493 & & & Model Fit \\
RMSEA & 0,075 & & & Model Fit \\
CFI & 0,98 & & $p=0,150$ & Model Fit \\
SRMR & 0,042 & & & Model Fit \\
\hline
\end{tabular}

Hasil pengujian terhadap model pengukuran beban kerja mental Teruji saat interaksi dalam asuhan keterujian dengan empat model pengukuran yang dispesifikkan ke dalam sebelas jenis instrumen menghasilkan $p$-value $=0,150(p>0,05)$ dan RMSEA $=0,075$ (RMSEA $<0,1)$. Berdasarkan data tersebut maka dapat disimpulkan bahwa model pengembangan alat ukur beban kerja mental dapat memenuhi persyaratan dan berada pada indeks kecocokan, sehingga model pengukuran beban kerja mental Teruji saat interaksi dalam asuhan keterujian dapat dipertimbangkan untuk dipergunakan.

\section{DISKUSI}

Setiap individu memiliki sistem kepribadian tertentu, sistem interpersonal terbentuk karena adanya hasil interaksi antar individu untuk mencapai tujuan bersama. Dalam asuhan keperawatan fakta utama yang menentukan hubungan interpersonal adalah kemampuan interaksi dari perawatnya. Selama berinteraksi, perawat-klien akan dipengaruhi oleh jenis interaksi, kondisi klien, ketersediaan waktu, kemampuan berfikir kritis, kemampuan mengelola masalah, keseimbangan diri, dan kemampuan terhadap kontrol dirinya (King dalam Tomey, 2006).

Terjadinya selisih kapasitas maksimum perawat untuk melakukan upaya fisik, mental, pengelolaan waktu, penampilan kerja, perasaan frustrasi, dan usaha dengan pengaruhselamaperawatmelakukaninteraksi akan menyebabkan beban kerja mental.
Terjadinya beban kerja mengakibatkan aktivitas metakontrol sehingga menimbulkan perubahan fisik, mental, dan psikologis. Perubahan-perubahan tersebut memberikan informasi untuk pengembangan alat ukur beban kerja mental saat interaksi dalam asuhan keperawatan.

Dalam rangka pengembangan alat ukur ini peneliti melakukan uji coba di empat provinsi dengan partisipan berjumlah 195 orang. Sumber data diperoleh dariempatjenis partisipan, yaitu teruji, penguji, pendamping, dan klien. Karakteristik partisipan sebagian besar berjenis kelamin laki-laki, dengan tempat bekerja di ruang rawat bedah dan non bedah. Menurut Minetty dan Hutanson dalam Gillies (2003), ketergantungan perawat di ruang perawatan bedah termasuk kategori tingkat ketergantungan penuh (full care), sehingga perlu diperhitungkan beban kerja perawat dengan prediksi jumlah total klien yang dirawat, kategori perawatan, dan jumlah masing-masing kebutuhan perawatan. Berdasarkan hasil studi pendahuluan terhadap 150 perawat bedah di Jawa Barat diperoleh hampir 83,4 persen bekerja dalam kondisi beban kerja mental.

Menurut King dalam Tomey (2006) dalam berinteraksi perawat harus mampu menempatkan dirinya sebagai "I and Self". Bila dikaitkan dengan hasil penelitian sebelumnya, interaksi perawat dibutuhkan dalam setiap titik pelayanan rawat bedah bila tidak dilaksanakan akan berpengaruh terhadap keselamatan klien, misalnya terjadinya sentinel, keterlambatan 
pengobatan, kesalahan identifikasi klien, pelayanan rawat darurat yang tidak diinginkan, ataupun kematian.

Untuk itu pengembangan alat ukur terhadap partisipan kelompok Teruji ini betulbetul telah memenuhi persaratan kriteria pengambilan sampel. Pengembangan alat ukur ini merupakan hal yang baru sehingga membutuhkan proses perumusan alat ukur agar dapat menjelaskan kombinasi variabel pembentuk alat ukur. Proses perumusan alat ukur meliputi proses menerjemahkan beban kerja mental, pengelompokan ke dalam blue print perubahan fisik, psikologis, dan perilaku yang terjadi akibat beban kerja mental. Pengukuran beban kerja mental ini diukur pada konteks interaksi dalam asuhan keperawatan yang dirumuskan berdasarkan teori Imogene King dan teori Hildegard Peplau. Fenomena yang didapatkan dari hasil studi pendahuluan diperoleh interaksi dilakukan sebelum, selama, dan setelah interaksi. Perubahan psikologis terlihat dari perubahan fisik dan perilaku. Teruji lebih suka didampingi oleh pendamping dibandingkan dengan atasan sehingga objektivitasnya perlu diperkuat oleh angket yang berasal dari klien.

Hasil pengujian validitas dan reliabilitas telah dilakukan terhadap 35 butir pertanyaan yang dilakukan sebelum dan setelah interaksi. Hasil alat ukur untuk Teruji sebelum interaksi didapatkan nilai case processing summary sebesar 97,4 persen, artinya banyaknya instrumen yang mengikuti proses tersebut, nilai $p=0,993(p>0,7)$, sehingga perlu diuji kembali dengan interitem correlation dan hasilnya banyak diperoleh butir pertanyaan yang memiliki keterikatan lebih dari 0,7 dan kemungkinan beberapa butir pertanyaan dijawab sama oleh Teruji.

Kemungkinan faktor penyebab dari butir pertanyaan yang berada dalam satu kelompok dijawab hampir sama oleh perawat adalah pada saat dilakukan penelitian tiap
Teruji menangani klien lebih dari satu klien dan hasil studi pendahuluan menunjukkan penyebab beban kerja mental tersebut adalah tentang keterbatasan waktu dan konsekuensi tugas. Hasil penelitian terhadap beban kerja mental saat interaksi dalam asuhan keperawatan menunjukkan tekanan waktu menempati indeks tertinggi dengan nilai 833.

Kondisi-kondisi di atas menunjukkan bahwa jawaban Teruji terhadap instrumen Teruji sebelum berinteraksi tidak terfokus sehingga untuk jawaban yang sama terhadap butir pertanyaan yang berbeda tidak dibaca secara lengkap dan disesuaikan dengan kondisi dirinya. Menurut pendapat Cain (2004), bila seseorang sudah tidak dapat beradaptasi terhadap keterbatasan waktu, impuls ke korteks adrenalnya akan terhambat sehingga akan memengaruhi kegiatan hormon adrenalin untuk menyeleksi kesalahan dan penentuan akibat keadaan darurat.

Bila dikaitkan dengan pendapat King (Tomey \& Alligood, 2006), pencapaian tujuan dapat terjadi bila individu mampu beradaptasi melalui melalui proses Dynamic Interacting System. Peran perawat adalah untuk membantu memahami dan menggali apa yang klien ketahui, sebagai suatu sistem terbuka dan sebagai "I and Self by his or her". Bila jawaban Teruji terhadap instrumen Teruji sebelum berinteraksi saja sudah tidak terfokus maka untuk selanjutnya perawat kemungkinan tidak mampu untuk menyeleksi kesalahan dan penentuan kondisi kritis. Sementara perawat harus mampu menempatkan perannya dengan baik.

Hasil observasi yang dilakukan oleh pendamping dari 60 butir pertanyaan diperoleh $p=0,928$ sebelum interaksi dan $p=0,907$ setelah interaksi. Hal ini berarti butir pertanyaan untuk pendamping selama observasi telah menunjukkan angka reliabel. 
Hasil case processing summary butir pertanyaan sebelum interaksi sebesar 96,9 persen, artinya pendamping melakukan penilaian tentang kebiasaan Teruji saat berinteraksi selama satu tahun terakhir sebanyak 189 orang dan hasil case processing summary butir pertanyaan setelah interaksi sebesar 92,3 persen (181 orang). Hasil corrected butir pertanyaan didapatkan data bahwa tidak terdapat pertanyaan yang memiliki nilai di bawah 0,2 , sehingga semua butir pertanyaan observasi pendamping sebelum dan selama berinteraksi dapat digunakan.

Hasil analisis hubungan antar butir pertanyaan, untuk butir pertanyaan pendamping menunjukkan korelasi $p>0,7$, artinya bahwa antar butir pertanyaan pendamping memiliki keterikatan yang kuat dan antar butir pertanyaan dijawab hampir sama. Tujuan awal dibuatnya instrumen obeservasi awal dari pendamping ini adalah untuk mencegah hasil observasi yang bersifat subjektif dan untuk membantu proses content analysis.

Menurut Neuendorf (2002), analisis konten perlu memasukkan sejumlah besar informasi tekstual secara sistematis untuk mengidentifikasi sifat dan kata kunci yang paling sering digunakan. Keberadaan instrumen pendamping penguji ini dapat dikategorikan sebagai informasi tekstual sehingga dapat dianggap menjadi quasievaluasi. Pendamping dan Teruji samasama berperan sebagai pemberi pelayanan keperawatan pada klien sehingga menyebabkan terjadinya keterikatan yang kuat antar butir pertanyaan dan pertanyaan dapat dijawab dengan jawaban yang hampir sama.

Hasil uji validitas dan reliabilitas terhadap butir pertanyaan observasi terdiri dari 6 hasil uji validitas dan reliabilitas yaitu sebelum interaksi dan selama interaksi yang terdiri dari fase orientasi, identifikasi, eksplorasi, dan resolusi kemudian setelah interaksi. Hasil uji validitas dan reliabilitas terhadap butir pertanyaan sebelum berinteraksi terdiri dari 21 butir pertanyaan yang merupakan pertanyaan untuk melihat perubahan psikologis, fisik, dan perilaku. Tahapan kegiatan yang diobservasi diawali ketika perawat mempersiapkan diri untuk berinteraksi. Dari 196 orang perawat didapatkan hasil nilai case processing summary untuk butir pertanyaan sebelum interaksi sebesar 100 persen dan nilai Cronbach 0,865 $(>0,7)$, artinya bahwa keterikatan dan kesamaan jawaban antar butir pertanyaan menunjukkan angka yang bervariasi berkisar antara 0,850 sampai 0,013 .

Variasi keterikatan dan kesamaan jawaban ini menunjukkan kemampuan interaksi melalui pengembangan interaksi yang bersifat dinamis sebagaimana dikemukakan oleh King dalam Tomey (2006). Untukmelaluitahapan hubunganinterpesonal yang dikembangkan oleh Hildegard Peplau, perawat membutuhkan kemampuan adaptasi yang baik, sehingga akan mengalami beban kerja mental yang bervariasi. Menurut teori adaptasi yang dikemukakan oleh Roy dalam Tomey \& Alligood (2014), kesatuan informasi yang diterima sebagai stimulus sebelum berinteraksi akan menghasilkan stimulus fokal, kontekstual, dan residual yang bervariasi. Rangsangan yang datang mengakibatkan Teruji harus mempersiapkan interaksi untuk mendorong stimulus kontekstual dan residual Teruji secara internal dan eksternal sampai menimbulkan respons perubahan psikologis, fisik, dan perilaku. Teruji akan belajar beradaptasi terhadap stimulus-stimulus tersebut melalui empat mode mekanisme adaptasi bagaimana mempertahankan dirinya untuk tetap berada dalam kontrol diri yang baik untuk menjalankan perannya berinteraksi dalam asuhan keperawatan. 
Hasil uji reliabilitas dan validitas selama fase orientasi, Teruji melakukan kontrak awal untuk membangun kepercayaan dan pengumpulan data. Dari analisis data terhadap 29 butir pertanyaan menghasilkan Cronbach $0,755(p>0,7)$ artinya perawat yang melalui tahapan ini sebanyak 178 orang. Keterikatan dan kesamaan jawaban untuk tiap butir pertanyaan yang bervariasi dari 0,850 sampai 0,014 . Ketidakterikatan dan ketidaksamaan artinya memiliki nilai hubungan yang negatif di setiap butir pertanyaan, terdapat dalam butir pertanyaan berikut:

a. Bingung dengan butir pertanyaan remasan saat jabat tangan, genggaman saat jabat tangan, mengepal jemari, dan terjadinya Tik (gerakan otot involunter yang tiba-tiba dan terjadi berkali-kali) di wajah.

b. Emosi dengan butir pertanyaan bingung, jabat tangan, genggaman saat jabat tangan, mengepal jemari dan terjadinya Tik (gerakan otot involunter yang tibatiba dan terjadi berkali-kali) dan gerakan bahu saat menarik nafas.

c. Peka stimulus dengan butir pertanyaan jabat tangan, genggaman saat jabat tangan, mengepal jemari dan terjadinya Tik (gerakan otot involunter yang tibatiba dan terjadi berkali-kali) di bahu.

d. Menyatukan kedua jemari dengan mengungkapkan kata "maksud saya"

e. Mempercepat topik dan mengenggam tangan klien.

Berdasarkan telaah hasil hubungan tiap pertanyaan dikaitkan dengan pendapat Neuendorf (2002) bahwa analisis konten merupakan langkah memasukkan sejumlah besar informasi tekstual secara sistematis untuk mengidentifikasi sifat-sifatnya, seperti frekuensi kata kunci yang paling sering digunakan dengan menempatkan struktur yang lebih penting dari isi komunikasi. Berdasarkan jumlah tersebut informasi tekstual dikategorikan untuk memberikan pembacaan yang berarti konten dengan membuat kerangka koding. Sehingga dibutuhkan pengembangan alat ukur yang lebih spesifik lagi pada fase orientasi karena ada beberapa informasi tekstual dari perubahan psikologis, fisik dan perilaku sesuai dengan struktur dari isi komunikasi.

Sesuai dengan pendapat King dalam Tomey (2006) tentang pengembangan teorinya, Dynamic Interaction system, diperlukan proses persepsi dan komunikasi antara individu dengan individu, kelompok dan lingkungannya yang dimanifestasikan sebagai perilaku verbal dan non-verbal, untuk menempatkan peran sesuai posisinya sebagai klien dan sebagai perawat yang memberikan pelayanan. Dari hasil analisis untuk rumah sakit yang termasuk dalam penelitian sesuai dengan perkembangan emosi, pengalaman, keunikan, dan area dilaksanakan interaksi, ternyata jabat tangan, genggaman tangan dari jawaban penguji memiliki ketidakterikatan antar butir pertanyaan, artinya sangat dimungkinkan pertukaran energi dan informasi antara perawat dengan klien tidak membantu untuk keseimbangan dan mengontrol stresor kebingungan emosi dan kepekaan terhadap stimulus. Untuk pengembangan alat ukur yang terkait dengan beban kerja mental saat orientasi dalam asuhan keperawatan diperlukan telaahan yang lebih spesifik lagi terkait dengan perubahan psikologis.

Pada fase identifikasi butir pertanyaan diarahkan pada perubahan fisik, psikologis, dan perilaku selama Teruji melakukan fasilitasi ekspresi perilaku klien untuk menggali potensi kemandirian klien dan memberi bantuan keperawatan yang dibutuhkan klien. Dalam fase ini nilai untuk butir pertanyaan sebesar 91,8 persen, yang diikuti oleh 176 Teruji dengan 27 butir pertanyaan. Kegiatan ini menghasilkan nilai Cronbach $0,820(>0,7)$, artinya pada fase ini 
27 butir pertanyaan reliabel untuk dijadikan alat ukur.

Hasil analisis hubungan tiap pertanyaan menunjukkan keterikatan dan kesamaan jawaban penguji yang bervariasi dari 0,961 sampai 0,020 . Ketidakterikatan dan ketidaksamaan jawaban penguji atau bernilai negatif terdapat dalam butir pertanyaan berikut:
a. Cemas dengan gerakan sentuhan tangan kepada klien.
b. Peka stimulus dengan gerakan jemari tangan.
c. Perubahan warna wajah dengan kemampuan memfokuskan.
d. Pengungkapan "maksud saya" dengan menarik nafas.
e. Mengganti topik dengan pengungkapan "maksud saya"

Kemandirian klien dan bantuan keperawatan yang dibutuhkan klien berbedabeda sehingga dibutuhkan kemampuan Teruji untuk berfikir kritis. Pada tahap ini diperlukan kemampuan Teruji untuk memberikan bantuan pada klien sesuai dengan kebutuhannya (Huber, 2006).

Hasil analisis pada tahap identifikasi Teruji, dalam mengungkapkan ide Teruji tidak mengubah perilaku sentuhan jemari tangan, berusaha mengklarifikasi, menarik nafas, dan mengganti topik. Menurut Rubio, dkk. (2004), selama proses belajar terutama dalam kaitannya dengan interaksi antar manusia dapat digunakan berbagai media. Selama fase identifikasi Teruji menggunakan berbagai fasilitas media seperti barang medis habis pakai, gambar, dan peralatan medis.

Topik yang dipilih oleh Teruji untuk tahap identifikasi, sangat didukung oleh kemampuan berpikir Teruji sehingga membantu penguji melihat perubahan perilaku Teruji melalui pengungkapan ide, penyampaian informasi, bertukar pengalaman dengan klien, menghubungkan fakta, memberi bukti-bukti, contoh solusi, atau kesimpulan yang diambilnya termasuk memberi penjelasan mengenai keuntungan (kelebihan) dan kerugian (kekurangan) dari tindakan yang akan diakukan Teruji. Oleh karena itu untuk pengembangan alat ukur selanjutnya dibutuhkan spesifikasi perilaku yang ditampilkan Teruji yang lebih memperdalam mengenai ungkapan perilaku perawat selama berpikir kritis.

Fase eksplorasi yang merupakan fase klien merasakan nilai hubungan dengan peran keperawatan untuk membantu klien untuk mendapatkan gambaran kondisi dan seluruh aspek yang terlibat di dalamnya. Hasil uji reliabilitas dihasilkan analisis Cronbach 0,764 artinya 24 butir pertanyaan tersebut dapat digunakan untuk mengukur beban kerja mental perawat saat eksplorasi dengan keterikatan di setiap butir pertanyaan menunjukan variasi 0,509 sampai 0,023 , hasil ini menunjukkan bahwa tiap butir pertanyaan dalam posisi tidak terlalu terikat dan terdapat variasi jawaban saat penguji menilai Teruji.

Pada fase resolusi dimana penguji mengamati perubahan psikologis, perilaku dan fisik Teruji untuk melakukan penguatan kemampuan klien untuk memenuhi kebutuhannyasendiridanmenyalurkanenergi ke arah realisasi potensi serta melepaskan permasalahannya dengan Teruji. Hasil uji reliabilitas diperoleh nilai Cronbach 0,842 artinya 24 butir pertanyaan untuk melihat perubahan perilaku, psikologis dan fisik pada fase resolusi dapat dikembangkan. Hasil analisis keterikatan setiap butir pertanyaan diperoleh variasi nilai keterikatan dan kesamaan jawaban penguji berdasarkan hasil pengamatan Teruji 0,704 sampai 0,08, artinya bahwa terdapat beberapa butir pertanyaan yang memiliki keterikatan dan kesamaan jawaban. Pada tahap ini tidak dibutuhkan angka ketidakterikatan dan ketidaksamaan jawaban sehingga dikatakan butir pertanyaan memenuhi persyaratan 
penuh sebagai alat ukur.

Pada fase setelah interaksi, observasi dilakukan untuk melihat perubahan fisik, psikologis dan perilaku Teruji setelah berinteraksi. Reliabilitas yang dihasilkan pada tahapan ini diperoleh Cronbach 0,781 $(p>0,7)$ artinya 24 butir pertanyaan untuk melihat perubahan perilaku, psikologis dan fisik pada fase setelah interaksi dapat dikembangkan. Angka keterikatan dan kesamaan di setiap butir pertanyaan adalah 0,013 sampai 0,638 . Hasil ini menunjukkan bahwa tiap butir pertanyaan dalam posisi tidak terlalu terikat dan terdapat variasi jawaban saat penguji menilai Teruji.

Berdasarkan tabel hasil uji coba validitas dan reliabilitas pada draft pertama terdapat sembilan butir pertanyaan alat ukur yang tidak valid dengan $r<0,3$ yang terdapat dalam lembar angket pendamping untuk butir pertanyaan observasi perilaku "mengepal." Sedangkan pada butir pertanyaan penguji pada kata "marah, sensitive dan remasan tangan" pada tahapan interaksi fase orientasi dan eksplorasi, resolusi, dan setelah interaksi. Untuk mendapat hasil dengan reliabilitas dan validitas yang lebih baik pada lampiran kedua dan ketiga maka peneliti memperbaiki kalimat "marah" menjadi "emosi meningkat," kata "sensitif" diubah menjadi kalimat "peka terhadap stimulus" kemudian kata "mengepal" diubah menjadi "mengenggam" dan kalimat "remasan tangan saat menjabat tangan klien diubah menjadi "kekuatan genggaman tangan pada klien".

Berdasarkan hasil analisis pengolahan data terlihat bahwa model pengembangan alat ukur beban kerja mental saat interaksi dalam asuhan keperawatan pada Confirmatory Factor Analysis (CFA), sudah memenuhi kriteria goodness of fit yang telah ditetapkan > nilai kemungkinan pengujian goodness of fit menunjukkan nilai $p$-value $150(>0,05)$ dan RMSEA 0,075 (>0,05), hasil tersebut belum memenuhi nilai $p$-value for test of close fit, tetapi sudah memenuhi kriteria model yang cocok menurut Ghozali dan Fuad (2005), nilai RMSA berkisar 0,01= $-0,08$ menujukkan nilai yang cukup tepat. Hasil uji kecocokan model dengan yang lain seperti GFI (Goodness of Fit Index), RFI (Relative Fit Index), NFI (Normed Fit Index), IFI (Incremental Fit Index) juga memperlihatkan nlai $p>0,90$ sehingga model dinyatakan tepat.

Hasil uji modifikasi model alat ukur persepsi Teruji, observasi pendamping, observasi dari penguji, dan angket klien terhadap beban kerja mental diperoleh hasil pendamping, klien, dan penguji memberikan kontribusi yang signifikan terhadap pengembangan alat ukur beban kerja mental sedangkan hasil persepsi tidak memberikan kontribusi yang signifikan terhadap pengukuran beban kerja mental. Apabila dikaitkan dengan hasil pengamatan secara empiris terjadi perubahan fisik dan perubahan perilaku terutama terlihat sebelum Teruji memulai interaksi menggunakan ratarata waktu 20 menit sedangkan untuk fasefase selama interaksi menggunakan ratarata waktu di bawah 10 menit.

Kondisi ini menggambarkan bahwa sebelum interaksi Teruji cenderung menunda waktu dan selama interaksi cenderung ingin cepat menyelesaikan pekerjaan. Sehingga dapat dikatakan pada saat mengisi alat ukur beban kerja mental sebelum dan setelah observasi bagi dan hasil perubahan empiris yang dibutuhkan oleh penguji dipengaruhi oleh faktor beban kerja mental.

Beberapa hasil penelitian sebelumnya tentang pengukuran beban kerja mental perawat, antara lain Cain (2004), menjelaskan bahwa ketidaksepakatan, refleksi konstruksi mental karena adanya keterbatasan waktu, rangsangan konstruksi mental yang bersifat laten, tugas yang bersifat kompleks, kecemasan, tekanan emosional, kemampuan menjalankan tugas, dan 
keterbatasan waktu, menghambat reaksi ke korteks adrenal. Hal ini akan memengaruhi kegiatan hormon adrenalin yang berdampak terhadap penurunan kemampuan molekul adrenalin untuk menyeleksi kesalahan dan penentuan akibat keadaan darurat. Hal ini sangat sesuai dengan hasil studi pendahuluan yakni ketidaksepakatan dalam tugas dan keterbatasan waktu dapat memengaruhi beban kerja mental perawat untuk berinteraksi dalam asuhan keperawatan.

Hasil telaah di atas bila dikaitkan dengan hasil penelitian Kelly, dkk. (2006) yang melakukan penelitian mengukur beban kerja mental terdapat hubungan sistem interaksi pertanyaan dan jawaban dari Teruji terhadap kemampuan sensitivitas individu terhadap diri, tugas, usia, tingkat pendidikan, tipe pekerjaan, dan pengalaman kerja. Hasil penelitian terdapat perbedaan hasil observasi dan persepsi dari Teruji sendiri menunjukkan kurangnya sensitivitas individu terhadap diri sendiri ketika menjawab setiap butir pertanyaan pada angket yang membahas kondisi beban kerja mental dirinya.

Hasil penelitian Mitchell menyatakan terdapat hubungan beban kerja mental dengan penampilan kerja pada tugas sekunder. Karena pengisian alat ukur untuk Teruji dianggap merupakan pekerjaan sekunder, jawaban pertanyaan tidak terfokus dan tidak dijawab secara hatihati dari mulai membaca petunjuk pengisian maupun melewati fase-fase interaksi dengan lengkap padahal Teruji sudah dilatih perihal definisi operasional dalam butir pertanyaan dan sudah dijelaskan dalam panduan terkait pemilih angka-angka yang berada dalam skala.

Kondisi di atas sesuai dengan hasil penelitian yang dilakukan Parasuraman, Sheridan, Wickens (2008), yaitu terdapat hubungan kesadaran terhadap situasi, penampilan kerja, dan lingkungan kerja.
Pengembangan alat ukur beban kerja mental saat interaksi, diukur secara subjektif untuk menganalisis pengaruh kesadaran Teruji terhadap situasi, beban kerja mental, dan tingkat kepercayaannya terhadap penampilan kerja.

Menurut Dekker \& Hollnagel (2004), terdapat beberapa faktor yang berhubungan dengan kesadaran terhadap situasi, beban kerja mental, dan tingkat kepercayaan. Menurut psikoanalisis Freud, kesadaran terhadap situasi beban kerja mental, kerangka pikir dan definisi operasional akan berdampak pada faktor untuk mengukur kesadaran diri. Bila dikaitkan dengan hasil penelitian, meskipun kerangka teori dan definisi operasional telah dibentuk sedemikian rupa untuk mengakomodasi kegiatan interaksi saat asuhan keperawatan, melalui pengembangan teori interaksi manusia dalam sistem yang dijelaskan secara spesifik sesuai dengan kesadaran terhadap situasi, beban kerja mental dan rasa percaya tetap karena bersifat sangat subjektif dan membutuhkan kemampuan sensitivitas untuk menjawab setiap butir pertanyaan.

Menurut Patel (2002), kemampuan manusia untuk memproses informasi dengan mengukur kemampuan kognitif, kelelahan, stres, kecemasan, keterampilan memperbaiki komponen dengan menggunakan analisis regresi beban kerja mental sangat dipengaruhi oleh kemampuan kognitif. Dari hasil penelitian dan dari evaluasi kejadian empiris terdapat perbedaan signifikansi antara persepsi Teruji dengan hasil observasi penguji dan pendamping Teruji, maka dapat dikatakan bahwa kemampuan kognitif dari Teruji kemungkinan mengalami penurunan saat mengisi butir pertanyaan dan kemungkinan akibat merasa diperhatikan sehingga menjadi pencetus terjadinya beban kerja mental atau Teruji memang sudah mengalami beban 
kerja mental yang sudah terakumulasi dari faktor pencetus dalam jangka waktu yang panjang sehingga merangsang penggunaan fungsi otak yang memicu reaksi fungsional dari pusat kesadaran korteks serebri.

Korteks serebri merupakan bagian otak depan yang paling berkembang sempurna terdiri atas lobus kanan dan lobus kiri. Bagian otak ini fungsinya berkaitan dengan intelegensi, proses berpikir, berkreasi, dan lain-lain. Ketegangan akibat refleksi mental akan muncul berbagai gejala yang dapat dideteksi melalui pemeriksaan kemampuan adaptasi fisik sehingga berdasarkan rangkaian informasi di atas maka dapat dikatakan pengembangan alat ukur ini telah dapat mengindikasi adanya hubungan kerja antara fisik, psikologis, dan perilaku dalam merespons beban mental yang dapat memengaruhi pengisian angket persepsi dari Teruji.

Kontribusi yang tidak bermakna juga terdapat pada variabel fase eksplorasi saat observasi sangat berkaitan dengan fenomena Teruji yang cenderung mempercepat fase interaksi. Menurut Mitchell (2000), beban kerja dapat diukur melalui kemampuan memfokuskan perhatian, penyesuaian beban kerja, kemampuan memproses secara optimal, dan motivasi menyelesaikan tugas. Maka dalam penelitian ini didapatkan rendahnya nilaisignifikasieksplorasiterhadap observasi disebabkan oleh kemampuan Teruji untuk menyelesaikan fase eksplorasi yang merupakan penggalian ketidakmauan, ketidaktahuan, dan ketidakmampuan klien untuk memenuhi kebutuhan dasarnya. Penggalian ini sangat dipengaruhi oleh kompetensi, kemampuan menanggapi, kemampuan memfokuskan perhatian, kemampuan mengikuti proses kerja secara optimal, dan motivasi menyelesaikan tugas, sehingga Teruji banyak yang tanpa sengaja melewati fase tersebut.
Pengembangan alat ukur observasi juga memiliki keterkaitan yang kuat, sedangkan untuk pengembangan alat ukur pendamping dan persepsi memiliki keterkaitan yang rendah yaitu 0,18 untuk persepsi perawat dan 0,25 untuk pendamping. Secara empiris keterkaitan yang rendah antara lajur hubungan beban kerja mental dengan alat ukur persepsi Teruji dengan hasil observasi pendampingadalahorang darikelompokyang sama sehingga kemungkinan dipengaruhi oleh faktor subjektivitas dan sensitivitas dalam menjawab butir pertanyaan. Hal ini dapat dlihat dari hasil uji-t yang dihasilkan dari penelitian setelah mengalami modifikasi model.

Berdasarkan pengujian terhadap model pengukuran beban kerja mental perawat saat interaksi dalam asuhan keperawatan dengan 4 model pengukuran yang disertakan ke dalam sebelas jenis instrumen menghasilkan $p$-value $=0,150(p>0,05)$ dan RMSEA $=0,075$ (RMSEA $<0,1)$, sehingga dapat disimpulkan bahwa model pengembangan alat ukur beban kerja mental dapat memenuhi pesyaratan berada pada indeks kecocokan, sehingga model pengukuran beban kerja mental perawat saat interaksi dalam asuhan keperawatan dapat dipertimbangkan untuk dipergunakan.

Pengembangan alat ukur beban kerja mental saat interaksi dalam asuhan keperawatan ini melibatkan pemrosesan melalui 2 jenis pengujian validitas dan reliabilitas dengan program analisis yaitu program SPSS dengan program Lisrel. Hasil uji hubungan antar butir pertanyaan untuk semua alat ukur dan semua tahapan yang dilalui selama interaksi menunjukkan angka yang sangat bervariasi. Peneliti mendapatkan kesulitan membangun model pengembangan alat ukur untuk mendapatkan nilai confirmatory factor analysis (CFA) dengan menggunakan KMO (Kaiser Meyer Oikin) dengan jenis jawaban yang terdiri 
dari dua jenis, yaitu skala interval dan ordinal. KMO hanya bisa memproses CFA yang dibentuk oleh skala interval sehingga dalam mengembangkan model peneliti menggunakan analisis pemodelan melalui analisis program Lisrel.

Hasil analisis dengan regresi berganda yaitu CFA melalui modifikasi terhadap dua order analisis program Lisrel diperoleh nilai eigenvalue $>1$, $p$-value $>0,5$, RMSEA $<0,08$ untuk mendapatkan syarat nilai alat ukur yang cocok. Alasan peneliti tentang kecocokan model yang dibentuk dibuktikan pada butirbutir pertanyaan dengan nilai-nilai yang valid. Kekuatan dari setiap butir pertanyaan tersebut apabila tidak terjawab secara hatihati maka Teruji dan pendamping sudah tidak dapat memfokuskan diri terhadap permasalahan yang ada di hadapannya. Kondisi ini dikatakan Teruji dan pendamping sudah tidak dapat lagi melakukan upaya fisik, mental, pengelolaan waktu, mengelola rasa frustrasi, dan effort. Menurut Cain (2004) dalam kondisi tersebut individu sudah berada dalam status beban kerja mental.

Alat ukur ini sangat baik untuk meningkatkan kemampuan adaptasi dan memberikan informasi bagi pengelola pelayanan keperawatan, maka sangat baik apabila penelitian berikutnya dikembangkan untuk mengukur kemampuan adaptasi beban kerja mental untuk perawat khususnya dalam asuhan keparawatan dan tenaga kesehatan lain dalam melakukan pelayanan kesehatan.

Hasil pengujian yang telah dipaparkan juga membuktikan adanya alat ukur beban kerja mental perawat saat interaksi dalam asuhan keperawatan. Hasil ini telah menunjukkan dapat mengukur subjektivitas dan kurangnya sensitivitas dalam pengisian dengan penggunaan signifikasi dan keterkaitan tiap konstruk terhadap beban kerja mental. Namun, alat yang dirancang ini tentunya memiliki kelamahan-kelemahan, sehingga penelitian selanjutnya diharapkan melakukan beberapa perbaikan seperti homogennya instrumen yang digunakan dan pengembangan skala alat ukur.

\section{SIMPULAN}

Alat ukur beban kerja mental perawat saat interaksi dalam asuhan keperawatan dengan menyertakan komponen perubahan fisik, psikologis, dan perilaku melalui pengamatan penguji, pengisian angket Teruji, pengamatan pendamping, dan pendapat klien terbukti valid dan reliabel. Berdasarkan "decision" pemodelan dengan melibatkan berbagai sumber partisipan penelitian ini jelas menunjukkan kecocokan karakteristiknya, sehingga alat ukur ini layak untuk dimanfaatkan.

Alat ukur ini dapat memberikan informasi diagnostik yang valid dan reliabel mengenai beban kerja mental dalam memberikan asuhan keperawatan sehingga dapat memberikan informasi pada pengelola keperawatan untuk menetapkan perawat yang layak dan tidak layak melakukan kontak langsung pada klien. Sumber informasinya sangat banyak, yaitu dapat berasal dari diri perawat sendiri, pendamping perawat, dan dari pihak luar yaitu penguji dan klien.

\section{DAFTAR PUSTAKA}

Cain, Brad. (2004). "A Review of the Mental Workload Literature". NATO RTO Defence Research, 4, 1-33. Brad-cain@ drdc_rddc.gc.ca.

Creswell, W. (2010). Research Design: Pendekatan Kualitatif, Kuantitatif dan Campuran (Achmad Fawaid, Penerjemah). Edisi pertama. (hIm. 7599). Yogyakarta: Pustaka Pelajar.

Dekker dan Hollnagel. (2004). "Human Factors and Folk Models: Cognition, Technology, and Work, 6, 79-86.

Departemen Kesehatan RI. (2009). "Sistem Kesehatan Nasional: Bentuk dan Cara Penyelenggaraan Pembangunan 
Nasional". Jakarta: Departemen Kesehatan.

Departemen Kesehatan RI. (2009). "UndangUndang Republik Indonesia Nomor 44 Tahun 2009 tentang RUmah Sakit". Jakarta: Departemen Kesehatan.

Departemen Kesehatan RI. (2014). "UndangUndang Republik Indonesia Nomor 38 Tahun 2014 tentang Keperawatan". Jakarta: Departemen Kesehatan.

Erickson dan Grove. (2004). "Why Emotions Matter: Age, Agitation, and Burnout Among Registered Nurses." Online Journal of Issues in Nursing. Vol. 13, No.1.DOI: 10.3912/OJIN. Vol13No01PPT01, 20 Juli 2004.

Gabbay dan Bukchin. (2009). "Does Daily Nurse Staffing Match Ward Workload Variability?". Three HospitalExperiences.

Gillies, R. (2003). "The Behaviours, Interactions, and Perceptions of Junior High School Students During Small-Group Learning". Journal of Educational Psycology, 95, 137-147. doi: 101.1037/0022-0663.95.1.137.

Ghozali, I. dan Fuad. (2005). Structural Equation Modelling: Teori, Konsep dan Aplikasi dengan Program Lisrel 8.5. Semarang: BP Undip.

Huber, L. (2006). Leadership and Nursing Management. $3^{\text {rd }}$ ed. AS: Saunders, Elsevier. $\quad 12$ September 2014. premisssion@elsevier.com. http://www. elseiver.com.

International Journal of Health Care Quality Assurance, 22(6), 625-641.

Joint Commision Resouces. (2005). "Issues and Strategies for Nurse Leader". Meeting Hospital Challenge Today (13115). AS.

Kelly, Diane, dkk. (2006). "Used Centered Eveluation of Interactive Question Answering Systems". Procedings of Centered Evaluation of Interactive Question Answering Systems Workshop at HLT-NAACL2006, 49-56. 12 Oktober 2014. http://control. nist.gov.amc/ atau emile.morse@nist.gov.

Koesyanto. (2008). "Hubungan antara Beban Kerja dengan Kelelahan Kerja Mengajar pada Guru Sekolah Dasar Se-Kecamatan Semarang Barat Tahun Ajaran 2006/2007". KEMAS, Vol. 3, No. 2, sitas 10 Juli 2012.

Maslach and Leiter. (2008). "Early Predictors of Job Burnout and Engagement". Journal of Applied Psychology, 93, 498512.

Mitchell, D.K. (2000). "Mental Workload and ARL Workload Modeling Tools". Aberdeen Proving Ground, MD, US Army Research Laboratory, Human Research \& Engineering Directorate: 35.

Nazir, M. (2003). Metode Penelitian. Ghalia Indonesia: Jakarta.

Neuendorf, (2002). The Content Analysis Guidebook. Thousand Oaks, CA: Sage. hIm. 10.

Parasuraman, Sheridan, T.B., and Wickens, C.D. (2008). "Situation Awareness, Mental Workload and Trust in Automation Profile Methods". International Association for Applied Psychology, 53(1),61-86. srubiova@psi.ucm.es.

Patel, H., dkk. (2002). "An Electrical-Circuit Model for Predicting Mental Workload in Computer based Tasks". Journal of the Chinese Institute of Industrial Engineers, 19(1), 11-15. salvendy@ecn.purdue. edu.

Peterson and Bredow. (2013). Middle Range Theories Application to Nursing Research. Philadelphia: Lippincott William and Wilkins.

Pheasant, Stephen. (1991). Ergonomics, Work, and Health. London: Macmillan Academic Professional, Ltd.

Rubio dkk. (2004). "Evaluation of Subjective Mental Workload: A Comparison of SWAT, NASATLX, and Workload Profile 
Methods". International Association Tomey and Alligood. (2014). Nursing for Applied Psychology, 53(1), 61-86. Theorists and Their Work. $4^{\text {th }}$ ed. srubiova@psi.ucm.es Philadelphia, F.A. Davis Company. Yustinus, Semiun. (2006). Kesehatan Mental. Yogyakarta: Kanisius. 